\title{
INVESTIGATION INTO EVALUATION OF AGRICULTURE INFORMATIZATION LEVEL BASED ON TWO-TUPLE
}

\author{
Peide Liu ${ }^{1}$, Xin Zhang $^{2}$ \\ ${ }^{1,2}$ Information Management School, Shandong Economic University, 250014 Jinan, China \\ E-mail: ${ }^{1}$ Peide.liu@gmail.com (corresponding author)
}

Received 18 May 2009; accepted 8 November 2010

\begin{abstract}
Agriculture informatization level is an important part of one country's modernization. It is important to construct reasonable agriculture informatization evaluation indicator system and propose the evaluation method for promoting the agriculture informatization. This paper firstly analyzes the research status of the indicator system and evaluation method of informatization at home and abroad. On the basis of the relative literatures, the evaluation indicator system of the agriculture informatization in China is constructed, and the evaluation model of the agriculture informatization based on two-tuple and the relative operators are also constructed. This model not only can be used to rank the orders of the different areas according to the informatization level, but also can realize the qualitative evaluation of the agriculture informatization of the different areas according to the evaluation system. Finally, the application example shows that the evaluation system of the agriculture informatization constructed in this paper is effective, and the evaluation method proposed in this paper is simple and easy to use.
\end{abstract}

Keywords: agriculture informatization, two-tuple, linguistic evaluation set.

Reference to this paper should be made as follows: Liu, P.; Zhang, X. 2011. Investigation into evaluation of agriculture informatization level based on two-tuple, Technological and Economic Development of Economy 17(1): 74-86.

JEL Classification: D81, N55, C44, O13.

\section{Introduction}

Agriculture informatization plays the key role in the process of achieving agriculture modernization, and the development of agriculture modernization must include the process of agriculture informatization. Based on the comprehensive development in the filed of agriculture and the application of modern information technology and information system, agriculture informatization provides the effective information support for the agricultural production-supply-marketing and the related management and service, in order to improve 
the agriculture efficiency and the agriculture productivity level. It's significant for promoting the healthy development of Chinese agriculture informatization to research the problems of the rural informatization construction and establish a scientific and reasonable evaluation indicator system (Deciger and Bi 2007).

Many researchers have proposed the concept of informatization. Machlup (1962) firstly proposed the concept of the knowledge industry and the correlative theory in his book which was called "The Production and Distribution of Knowledge in The United States". Porat and Rubin (1977) firstly systematically proposed the measurement method of the information economy in his book which called "Information Economy". He firstly used the ratio of information industry Gross National Product (GNP) to Gross National Product (GNP) and the ratio of information industry labors to occupied population as the measurement factor for analyzing the development of informatization. In 1965, Xiaosong Qiqing proposed the informatization indicator system which consists of four factors (information quantity, information assemble rate, the level of communicate principal part and information coefficient) and eleven secondary indicators to measure the level of social informatization, and he measured it with the index of informatization (Song 2001). In addition, a number of experts also discussed the issue of information (Ravi et al. 1999; Nagalingam and Lin 1998; Yu et al. 2005; Cho and Lee 2007; Zuo and Fu 2007; Jung et al. 2004; Yan and Li 2007; Information Week 500 2003). The study on the evaluation indicator system, such as nations and regions informatization, enterprises informatization and so on, has been relatively mature and perfect abroad now, and the rural informatization is evaluated according to region informatization.

International statistics information center of National Bureau of Statistics of China constructed the first informatization level evaluation indicator system in 1999. This system consists of six one-level indicator (Researching Group of China Informatization Level Research and Evaluation 2006), including the development and utilization of information resource, information network construction, the popularity and application of information technology, the development of information industry, informatization talents and informatization development policy. In February 2006, according to the indicator system which was recommended by International Telecommunication Union (ITU) and The Organization for Economic Cooperation and Development (OECD) and the China's national conditions, Researching Group of China Informatization Level Research and Evaluation proposed the secondary generation informatization level evaluation indicator system which emphasized the evaluation about infomatization application, including two parts: the overall index system of informatization level which evaluates the national informationzation level by calculating the total index of informatization evalation, and the department key additional indicator system of informatization level which is designed according to different characteristics of the government, public institution, enterprise and family's informatization level and can provide the more specific informatization statistic data and information.

Less research on agriculture informatization evaluation system has been carried out in China now, the main studies include: The commissioner of China Zhi Gong Dang Group of Chinese People's Political Consultative Conference (CPPCC) proposed the evaluation indicators of rural informatization (The group commisioner... 2007) and the indicators consisted of one overall indicator (i.e. the development level of rural informatization) and four one-class 
indicators (i.e. rural industry informatization, rural administrative management informatization, rural living consumption informatization and rural social resource informatization). Li et al. (2006) evaluated the informatization level from several aspects, such as the construction of information system hardware, information quantity of rural information system, the scale and quality of information promulgated by the web site, timeliness of information. Sheng (2005) evaluated the informatization level from six aspects, such as agriculture information resource, agriculture information infrastructure, the application of agriculture information and technology, agriculture information industry, agriculture information talents and external environment of agriculture informatization.

There are many informatization evaluation methods, such as method of the principal components analysis (Zhang 2006), multiple criteria method COPRAS (Kaklauskas et al. 2010), Grey Criteria Method (Zavadskas et al. 2010), Data Envelopment Analysis (DEA) (Hou 2005), the Fuzzy Synthetical Evaluation Method (Li and Luo 2005), comprehensive evaluation method Based on Analytic Hierarchy Process (AHP) and Gray Relation Analysis Method (Yang 2006), evaluation method based on Neural Network and so on. But only Sheng (2005) used the AHP method to evaluate the rural informatization.

Many decision makers are more inclined to express their opinions with linguistic information, owing to the complexity of objective circumstances and the lack of accurate decision data. On the basis of the above research, this paper proposed the directly linguistic evaluation method based on two-tuple and relative operators and established the correlative model of agriculture informatization evaluation; Finally, according to the evaluation example of agriculture informatization from four regions in Shandong province, the effective of the evaluation indicator and method is illustrated.

\section{Agriculture informatization evaluation indicator system}

\subsection{Establishment of indicator system}

On the basis of the above research and the correlative principle, such as scientificity, comparability, comprehensiveness, operability and expansibility, and combining with the actual conditions of agriculture in China, the paper proposes the indicator system as follows.

Table 1. Evaluation index Research of Agriculture Informatization

\begin{tabular}{ll}
\hline \multicolumn{1}{c}{ Index } & \multicolumn{1}{c}{ Introduction } \\
\hline A1 Rural informatization status & $\begin{array}{l}\text { including: organization position, planning and budgeting, per-capita } \\
\text { expenditure, expenditure growth rate }\end{array}$ \\
\hline $\begin{array}{l}\text { A2 Agriculture information } \\
\text { infrastructure }\end{array}$ & $\begin{array}{l}\text { including: telephone popularization rate of rural area, television popular- } \\
\text { ization rate of rural area, coverage rate of toll cable, county-level propor- } \\
\text { tion of rural area service station, information device(sever, computers, } \\
\text { switches, routers), network bandwidth, etc. }\end{array}$ \\
\hline $\begin{array}{l}\text { A3 Agriculture information ap- } \\
\text { plication }\end{array}$ & $\begin{array}{l}\text { including: improving productivity, improving management efficiency, } \\
\text { conversion ratio of agriculture science and technology achievements, } \\
\text { expressing farm products information, exchanging through network, etc. }\end{array}$ \\
\hline
\end{tabular}


The end of Table 1

\begin{tabular}{ll}
\hline \multicolumn{1}{c}{ Index } & \multicolumn{1}{c}{ Introduction } \\
\hline $\begin{array}{l}\text { A4 Agriculture information } \\
\text { resource }\end{array}$ & $\begin{array}{l}\text { including: the transmission rate of radio and television programs } \\
\text { concerning agriculture and economic, million person possession } \\
\text { quantity of web site concerning agriculture per-capita agriculture } \\
\text { library collection }\end{array}$ \\
\hline $\begin{array}{l}\text { A5 Agriculture information } \\
\text { talents }\end{array}$ & $\begin{array}{l}\text { including: the ratio of network and information technology talents to } \\
\text { agriculture scientific research personnel, education level of rural family } \\
\text { labor, the proportion of employee in rural economic information centre }\end{array}$ \\
\hline $\begin{array}{l}\text { A6 Agriculture information } \\
\text { industry }\end{array}$ & $\begin{array}{l}\text { including: per-capita throughput of post and telecommunication in } \\
\text { rural area, the ratio of gross product in consultation service industry } \\
\text { of agriculture information to rural GDP }\end{array}$ \\
\hline $\begin{array}{l}\text { A7 Organization and manage- } \\
\text { ment }\end{array}$ & $\begin{array}{l}\text { including: organization setting, regulations and rules, security man- } \\
\text { agement }\end{array}$ \\
\hline
\end{tabular}

\subsection{Introduction of evaluation indicator}

Rural informatization status: rural informatization status refers to the supporting strength of the government policy, and the status of rural informatization in the construction of rural area. Rural informatization needs governmental support, especially county-township and local government's support. The basic guarantee in informatization construction in rural area includes the following aspects, such as setting up some relative rules and regulations, carrying out the corresponding planning and investment, especially constructing the infrastructure constructions. Therefore, this indicator containes the following aspects: the organization status, planning and budget, per-capita expenditure, expenditure growth rate, etc.

Agriculture information infrastructure: agriculture information infrastructure mainly refers to many kinds of network. These can support the development and application of agriculture information resource, and the application of agriculture information technology, mainly including the traditional network (broadcast and television network, telephone network) and the modern network (rural economic information network). Agriculture information infrastructure is the foundation of agriculture informatization and the necessary premise that the agriculture information resource and the information technology can come into play. Agriculture informatization construction level reflects its development extent directly. Its mainly includes some following aspects: first, in the aspect of traditional network, the construction conditions can be measured based on the popularization of rural telephone and of rural television; second, modern information device, including network server, computer, switch device, router device and so on; third, service station, including the county and township proportion of setting up rural economic information service stations, the administrative villages of setting up the spot of rural economic information service and so on.

The application condition of agriculture information technology: according to widely applying modern information technology into the field of agriculture, the purpose 
of agriculture informatization construction can promote the continuous, steady and highly efficiency development of agriculture. We may say that agriculture information technology is the core and forerunner of agriculture informatization development, and the evaluation of the present application status of agriculture information technology is an important content in the evaluation of agriculture informatization construction. This indicator will be used to evaluate the application status of superior popularization information technology, such as internet technology and database technology: the proportion of rural internet user, the possession quantity of data resource, conversion ratio of agriculture science and technology achievements, information dissemination of farm products and online trading and so on.

The level of agriculture information resource: agriculture information resource is not only the essential content contained by the foundation structure of agriculture informatization, but also the remarkable symbol of the success in agriculture informatization construction. Its exploitation and utilization is the core content of agriculture informatization construction, mainly including that: first, document information resource which refers to some kinds of information saving on the medium of paper and can be evaluated by the per-capita agriculture library collection; Second, data information resource which refers to the digital information and network information resource saved on the disk and compact disk and can be evaluated by million person possession quantity of web site concerning agriculture; Third, simulation information resource which refers to the information sent in the form of television and broadcast and can be evaluated by the transmission rate of broadcast and television programs concerning agriculture and economy.

Agriculture informatization talents: professional informatization talents are the important premise of agriculture informatization construction in our nations, and the most important factors affecting the development of agriculture informatization. At present, employees in the rural economic information center are consisted of the core of agriculture information talents, and agriculture scientific research personnel are also the important components of agriculture information talent. Consequently, we selected the two indicators to evaluate this factor of agriculture information talent, which include the proportion of agriculture scientific research personnel and the employees in the rural economic information center.

The development of agriculture information industry: the development degree of agriculture information industry, to some extent, not only reflects the development level of agriculture informatization, but also directly reflects the general conditions of peasants who receive information service. At present, consultation service industry of agriculture information has a new start, and it will be the core industry of the development of agriculture information. Therefore, we choose the following two indicators to evaluate the development of the agriculture information industry: the ratio of gross product in consultation service industry to rural GDP, and per-capita throughput of post and telecommunication in rural area.

Organization and management: the development of agriculture informatization needs to be guided and managed by the government, so the level of organization and management in the process of agriculture informatization is also the vital symbol of evaluating the agriculture informatization level. This indicator is mainly used to evaluate in these aspects, such as the complete organization, the complete management system, and information security measures. 


\section{Evaluation method of agriculture informatization based on two-tuple}

Two-tuple model, proposed by Herrera, the Spanish professor, is a kind of information processing method. Its character is that it can effectively avoid the problem of information loss and distortion in the process of integrating and operating linguistic evaluation information by using two-tuple to express the linguistic evaluation information, so that the calculation results of linguistic information are more precise.

\subsection{Correlative properties of linguistic term set}

Supposed that $S=\left(s_{0}, s_{1}, \cdots, s_{l-1}\right)$ is a pre-defined and ordered linguistic term set with odds elements, and $S$ should satisfy the following properties:

(1) If $i>j$, then $s_{i} \succ s_{j}$, it means that $s_{i}$ is superior to $s_{j}$;

(2) There is the negative operator $n e g\left(s_{i}\right)=s_{j}$, which subjects to $j=l-i$;

(3) Max operator: $\max \left(s_{i}, s_{j}\right)=s_{i}$, if $s_{i} \geq s_{j}$, and it means that $s_{i}$ is not inferior to $s_{j}$;

(4) Min operator: $\min \left(s_{i}, s_{j}\right)=s_{i}$, if $s_{i} \leq s_{j}$, and it means that $s_{i}$ is not superior to $s_{j}$.

In practice, let $l$ be equal to $3,5,7,9$, etc. it can be defined as:

$S=\left(s_{0}, s_{1}, s_{2}\right)=$ (poor, fair, good).

$S=\left(s_{0}, s_{1}, s_{2}, s_{3}, s_{4}\right)=$ (very poor, poor, fair, good, very good).

$S=\left(s_{0}, s_{1}, s_{2}, s_{3}, s_{4}, s_{5}, s_{6}\right)=$ (very poor, poor, slightly poor, fair, slightly good, good, very good).

$S=\left(s_{0}, s_{1}, s_{2}, s_{3}, s_{4}, s_{5}, s_{6}, s_{7}, s_{8}\right)=$ (extremely poor, very poor, poor, slightly poor, fair, slightly good, good, very good, extremely good).

In order to prevent the loss of linguistic decision information, original discrete linguistic scale $S=\left(s_{0}, s_{1}, \cdots, s_{l-1}\right)$ should be expanded to continuous linguistic scale $s=\left\{s_{\alpha} \mid \alpha \in R\right\}$.

\subsection{Correlative concepts of two-tuple}

Definition 1 (Herrera and Martinez 2000): Let $S=\left(s_{0}, s_{1}, \cdots, s_{l-1}\right)$ be the linguistic term set, and $\beta \in[0, l-1]$ be the aggregated calculation result from the elements in the set $S$, then we can get two-tuple concerning to $\beta$ from the following function:

$$
\begin{gathered}
\Delta:[0, l-1] \rightarrow S \times[-0.5,0.5), \\
\Delta(\beta)=\left(s_{i}, \alpha\right),
\end{gathered}
$$

where $i=\operatorname{round}(\beta), \alpha=\beta-i, \alpha \in[-0.5,0.5)$.

Thesis 1 (Herrera and Martinez 2000): Let $S=\left(s_{0}, s_{1}, \cdots, s_{l-1}\right)$ be the linguistic term set, and $\left(s_{i}, \alpha\right)$ be a two- tuple, then utilize the inverse function $\Delta^{-1}$ to convert two- tuple into the correlative value $\beta \in[0, l-1]$ :

$$
\begin{gathered}
\Delta^{-1}: S \times[-0.5,0.5) \rightarrow[0, l-1], \\
\Delta^{-1}\left(s_{i}, \alpha\right)=i+\alpha=\beta .
\end{gathered}
$$


It can be seen that two-tuple concerning to $s_{i}(i=0,1, \cdots, l-1)$ is $\left(s_{i}, 0\right)$.

Based on the above definition, we can easily conclude the correlative operational model of two- tuple, including two-tuple comparison, negative operator and aggregative operator.

1. Two-tuple comparison: supposed that $\left(s_{i}, \alpha_{1}\right)$ and $\left(s_{j}, \alpha_{2}\right)$ are any two two-tuple, then: If $i>j$, then $\left(s_{i}, \alpha_{1}\right)>\left(s_{j}, \alpha_{2}\right)$ represents that $\left(s_{i}, \alpha_{1}\right)$ is superior to $\left(s_{j}, \alpha_{2}\right)$.

If $i=j$ and $\alpha_{1}=\alpha_{2}$, then $\left(s_{i}, \alpha_{1}\right)=\left(s_{j}, \alpha_{2}\right)$ represents that $\left(s_{i}, \alpha_{1}\right)$ is equal to $\left(s_{j}, \alpha_{2}\right)$. If $i=j$ and $\alpha_{1}>\alpha_{2}$, then $\left(s_{i}, \alpha_{1}\right)>\left(s_{j}, \alpha_{2}\right)$.

If $i=j$ and $\alpha_{1}<\alpha_{2}$, then $\left(s_{i}, \alpha_{1}\right)<\left(s_{j}, \alpha_{2}\right)$ represents that $\left(s_{i}, \alpha_{1}\right)$ is inferior to.

2. There is the negative operator Neg, then Neg $\left(s_{i}, \alpha\right)=\Delta\left((l-1)-\left(\Delta^{-1}\left(s_{i}, \alpha\right)\right)\right)$.

3. If $\left(s_{i}, \alpha_{1}\right) \geq\left(s_{j}, \alpha_{2}\right)$, then $\max \left\{\left(s_{i}, \alpha_{1}\right),\left(s_{j}, \alpha_{2}\right)\right\}=\left(s_{i}, \alpha_{1}\right)$.

If $\left(s_{i}, \alpha_{1}\right) \leq\left(s_{j}, \alpha_{2}\right)$, then $\min \left\{\left(s_{i}, \alpha_{1}\right),\left(s_{j}, \alpha_{2}\right)\right\}=\left(s_{i}, \alpha_{1}\right)$.

Definition 2 (Herrera and Martinez 2000): Let $X=\left\{\left(x_{1}, \alpha_{1}\right), \cdots,\left(x_{n}, \alpha_{n}\right)\right\}$ be a group of being aggregated two-tuple, where $w=\left(w_{1}, w_{2}, \cdots, w_{n}\right)$ is the weight vector of the correlative two-tuple, then the two- tuple arithmetic weighted average operator (T-AWA) $\Psi_{2}$ is

$$
\Psi_{2}\left[\left(x_{1}, \alpha_{1}\right),\left(x_{2}, \alpha_{2}\right), \cdots,\left(x_{n}, \alpha_{n}\right)\right]=\Delta\left(\frac{\sum_{i=1}^{n} \Delta^{-1}\left(x_{i}, \alpha_{i}\right) w_{i}}{\sum_{i=1}^{n} w_{i}}\right)=\Delta\left(\frac{\sum_{i=1}^{n} \beta_{i} w_{i}}{\sum_{i=1}^{n} w_{i}}\right),
$$

where $\beta_{i}=i+\alpha_{i}$.

Definition 3 (Liao et al. 2006): Let $X=\left\{\left(x_{1}, \alpha_{1}\right), \cdots,\left(x_{n}, \alpha_{n}\right)\right\}$ be a group of being aggregated two-tuple, where $W=\left\{\left(w_{1}, \bar{\alpha}_{1}\right), \cdots,\left(w_{n}, \bar{\alpha}_{n}\right)\right\}$ is the weight vector of the correlative two-tuple, then the two two-tuple arithmetic weighted average operator (TT-AWA) $\Psi_{3}$ is

$$
\begin{aligned}
& \Psi_{3}\left[\left(\left(x_{1}, \alpha_{1}\right),\left(w_{1}, \bar{\alpha}_{1}\right)\right),\left(\left(x_{2}, \alpha_{2}\right),\left(w_{2}, \bar{\alpha}_{2}\right)\right) \cdots,\left(\left(x_{n}, \alpha_{n}\right),\left(w_{n}, \bar{\alpha}_{n}\right)\right)\right]= \\
& \Delta\left(\frac{\sum_{i=1}^{n} \Delta^{-1}\left(x_{i}, \alpha_{i}\right) \Delta^{-1}\left(w_{i}, \bar{\alpha}_{i}\right)}{\sum_{i=1}^{n} \Delta^{-1}\left(w_{i}, \bar{\alpha}_{i}\right)}\right)=\Delta\left(\frac{\sum_{i=1}^{n} \beta_{i} \bar{\beta}_{i}}{\sum_{i=1}^{n} \bar{\beta}_{i}}\right),
\end{aligned}
$$

where $\beta_{i}=\Delta^{-1}\left(x_{i}, \alpha_{i}\right)=i+\alpha_{i}, \bar{\beta}_{i}=\Delta^{-1}\left(w_{i}, \bar{\alpha}_{i}\right)=i+\bar{\alpha}_{i}$.

Definition 4 (Wei et al. 2006.): Let $X=\left\{\left(x_{1}, \alpha_{1}\right), \cdots,\left(x_{n}, \alpha_{n}\right)\right\}$ be a group of being aggregated two-tuple, then the two- tuple hybrid weighted arithmetic average operator (T-HWAA) $\Psi_{4}$ is

$$
\Psi_{4}\left[\left(x_{1}, \alpha_{1}\right),\left(x_{2}, \alpha_{2}\right), \cdots,\left(x_{n}, \alpha_{n}\right)\right]=\Delta\left(\sum_{i=1}^{n} \omega_{i} \gamma_{\sigma(i)}\right),
$$

where $\gamma_{\sigma(i)}$ is the $i^{t h}$ largest of the two- tuple weighted elements $\gamma_{k}\left(\gamma_{k}=n \lambda_{k} \beta_{k}, k=1,2, \cdots, n\right)$, $\beta_{k}=\Delta^{-1}\left(x_{k}, \alpha_{k}\right)$, and $n$ is balance coefficient. $\lambda=\left(\lambda_{1}, \lambda_{2}, \cdots \lambda_{n}\right)^{T}$ is the weight vector of $\left(x_{k}, \alpha_{k}\right)(k=1,2, \cdots, n)$, where $\lambda_{i} \in[0,1], \sum_{i=1}^{n} \lambda_{i}=1$. The weight vector $\omega=\left(\omega_{1}, \omega_{2}, \cdots, \omega_{n}\right)$ is the position vector, and it has no relation to $X=\left\{\left(x_{1}, \alpha_{1}\right), \cdots,\left(x_{n}, \alpha_{n}\right)\right\}$, where $\omega_{i} \in[0,1]$, and $\sum_{i=1}^{n} \omega_{i}=1$, and its formula is: 


$$
\omega_{i}=Q\left(\frac{i}{n}\right)-Q\left(\frac{i-1}{n}\right), i=1,2, \cdots, n,
$$

where

$$
Q(r)= \begin{cases}0, & \mathrm{r}<\alpha \\ \frac{r-\alpha}{\beta-\alpha}, & \alpha \leq r \leq \beta . \\ 1, & r>\beta\end{cases}
$$

In this formula, $\alpha, \beta, r \in[0,1]$, and the rules and values of the parameters are shown in Table 2.

Table 2. Relation between the fuzzy linguistic quantitative rules and values of the parameters

\begin{tabular}{cccc}
\hline The fuzzy linguistic quantitative rules & The most & Half at least & Many as possible \\
\hline Values of $(\alpha, \beta)$ & $(0.3,0.8)$ & $(0,0.5)$ & $(0.5,1.0)$ \\
\hline
\end{tabular}

\subsection{Evaluation procedure}

1. Description of the decision-making problems

Let $A=\left(a_{1}, a_{2}, \cdots, a_{m}\right)$ be the set of alternatives, $C=\left(c_{1}, c_{2}, \cdots, c_{n}\right)$ be the set of attributes, $E=\left(e_{1}, e_{2}, \cdots e_{p}\right)$ be the set of decision makers, and $S$ be the ordered linguistic evaluation set with odds elements. Supposed that $R^{k}=\left[r_{i j}^{k}\right]_{m \times n}$ is the linguistic decision matrix, where $r_{i j}^{k} \in S$ is a linguistic variable, given by the decision maker $e_{k}$, for the alternative $a_{i}$ with respect to the attribute $c_{j}$. Supposed that $W^{k}=\left(w_{1}^{k}, w_{2}^{k}, \cdots, w_{n}^{k}\right)$ is the weight vector of attributes, where $w_{j}^{k} \in S$ is a linguistic variable, given by decision makers $e_{k}$. Let $\lambda=\left(\lambda_{1}, \lambda_{2}, \cdots, \lambda_{p}\right)$ be the weight vector of decision makers, where $\lambda_{j} \in[0,1]$, and $\sum_{j=1}^{p} \lambda_{j}=1$. This decision problem is that, based on the linguistic decision matrix $R^{k}=\left[r_{i j}^{k}\right]_{m \times n}$, the weight vector of attributes $W^{k}=\left(w_{1}^{k}, w_{2}^{k}, \cdots, w_{n}^{k}\right)$, and the weight vector of decision makers $\lambda=\left(\lambda_{1}, \lambda_{2}, \cdots, \lambda_{p}\right)$, using some kinds of decision method, we can get the result of alternatives in order. The procedure of this decision problem is as follows.

2. Utilized the TT-AWA operator to aggregate the alternative $a_{i}$ in matrix $R^{k}=\left[r_{i j}^{k}\right]_{m \times n}$ into the overall preference value $z_{i}^{k}$ of the alternative $a_{i}$, given by decision maker $e_{k}$ :

$$
\begin{aligned}
& z_{i}^{k}=\Psi_{3}\left[\left(\left(r_{i 1}^{k}, 0\right),\left(w_{1}^{k}, 0\right)\right),\left(\left(r_{i 2}^{k}, 0\right),\left(w_{2}^{k}, 0\right)\right) \cdots,\left(\left(r_{i n}^{k}, 0\right),\left(w_{n}^{k}, 0\right)\right)\right]= \\
& \Delta\left(\frac{\sum_{j=1}^{n} \Delta^{-1}\left(r_{i j}^{k}, 0\right) \Delta^{-1}\left(w_{j}^{k}, 0\right)}{\sum_{j=1}^{n} \Delta^{-1}\left(w_{j}^{k}, 0\right)}\right)=\Delta\left(\frac{\sum_{j=1}^{n} \beta_{j} \bar{\beta}_{j}}{\sum_{j=1}^{n} \bar{\beta}_{j}}\right)=\left(x_{i}^{k}, \alpha_{i}^{k}\right) \\
& \beta_{j}=\Delta^{-1}\left(r_{i j}^{k}, 0\right), \bar{\beta}_{j}=\Delta^{-1}\left(w_{j}^{k}, 0\right)
\end{aligned}
$$


3. Utilized the T-HWAA operator to aggregate the overall preference value $z_{i}^{k}(k=1,2, \cdots, p)$ of the alternative $a_{i}$, given by every decision makers $e_{k}$, into collective overall preference value $z_{i}$ of the alternative $a_{i}$ :

$$
z_{i}=\Psi_{4}\left[\left(x_{i}^{1}, \alpha_{i}^{1}\right),\left(x_{i}^{2}, \alpha_{i}^{2}\right), \cdots,\left(x_{i}^{p}, \alpha_{i}^{p}\right)\right]=\Delta\left(\sum_{j=1}^{p} \omega_{j} \beta_{j}\right),
$$

where $\beta_{j}=p \lambda_{\sigma(j)} \beta_{\sigma(j)}$ is a kind of permutation, and $\beta_{\sigma(j)}$ is the $j^{\text {th }}$ largest elements of the set $\left(\beta_{1}, \cdots, \beta_{p}\right)$, where $\beta_{j}=\Delta^{-1}\left(x_{i}^{j}, \alpha_{i}^{j}\right), j=1, \cdots, p$, and $p$ is balance coefficient. $\lambda=\left(\lambda_{1}, \lambda_{2}, \cdots \lambda_{p}\right)^{T}$ is the weight vector of $\left(x_{i}^{1}, \alpha_{i}^{1}\right),\left(x_{i}^{2}, \alpha_{i}^{2}\right) \cdots,\left(x_{i}^{p}, \alpha_{i}^{p}\right)$, where $\lambda_{j} \in[0,1]$ and $\sum_{j=1}^{p} \lambda_{j}=1$. The weight vector $\omega=\left(\omega_{1}, \omega_{2}, \cdots, \omega_{p}\right)$ is the position vector, defined by formula (6), and it has nothing to

do with $X=\left\{\left(x_{i}^{1}, \alpha_{i}^{1}\right),\left(x_{i}^{2}, \alpha_{i}^{2}\right) \cdots,\left(x_{i}^{p}, \alpha_{i}^{p}\right)\right\}$, where $\omega_{j} \in[0,1]$, and $\sum_{j=1}^{p} \omega_{j}=1$.
4. Utilized $z_{i}(i=1,2, \cdots, m)$ to rank all alternatives.

5. End.

\section{Application Example}

We use the evaluation indicator shown in Table 1 to evaluate the agriculture informatization level of four regions in Shandong province. These regions are Shandong Province's agriculture demonstration zones, and all of them are in the better informatization conditions. In order to do an objective evaluation, we have invited three experts to assess the four regions. These experts are from university, government department in charge of agriculture and grass-roots agriculture department, and they have been engaged in agriculture informatization work with rich assess experience. Supposed that the weight vector of these experts is $\lambda=(0.4,0.3,0.3)$, and the linguistic evaluation set is $S=\left(s_{0}, s_{1}, s_{2}, s_{3}, s_{4}, s_{5}, s_{6}\right)$. The linguistic evaluation matrix and the weight information given by these experts are shown in Tables 3,4 and 5.

According to the above information, we can rank the informatization level of agriculture informatization of the four regions.

Evaluation steps of agriculture informatization level of the four regions are shown as follows:

1. According to the formula (8),

$$
\begin{aligned}
& z_{i}^{k}=\Delta\left(\frac{\sum_{j=1}^{n} \Delta^{-1}\left(r_{i j}^{k}, 0\right) \Delta^{-1}\left(w_{j}^{k}, 0\right)}{\sum_{j=1}^{n} \Delta^{-1}\left(w_{j}^{k}, 0\right)}\right)=\Delta\left(\frac{\sum_{j=1}^{n} \beta_{j} \bar{\beta}_{j}}{\sum_{j=1}^{n} \bar{\beta}_{j}}\right)=\left(x_{i}^{k}, \alpha_{i}^{k}\right) \\
& \beta_{j}=\Delta^{-1}\left(r_{i j}^{k}, 0\right), \bar{\beta}_{j}=\Delta^{-1}\left(w_{j}^{k}, 0\right)
\end{aligned}
$$

we can conclude that:

$$
\begin{gathered}
z_{1}^{1}=\left(s_{3},-0.32\right), z_{2}^{1}=\left(s_{2}, 0.36\right), z_{3}^{1}=\left(s_{3},-0.48\right), z_{4}^{1}=\left(s_{3},-0.4\right), \\
z_{1}^{2}=\left(s_{3},-0.304\right), z_{2}^{2}=\left(s_{2},-0.348\right), z_{3}^{2}=\left(s_{3},-0.435\right), z_{4}^{2}=\left(s_{2}, 0.435\right), \\
z_{1}^{3}=\left(s_{2}, 0.476\right), z_{2}^{3}=\left(s_{2}, 0.429\right), z_{3}^{3}=\left(s_{2}, 0.333\right), z_{4}^{3}=\left(s_{3},-0.476\right) .
\end{gathered}
$$


Table 3. The information of weight and linguistic evaluation offered by the first expert $\left(W^{1}=\left(w_{j}^{1}\right)_{7}\right.$ and $\left.R^{1}=\left(r_{i j}^{1}\right)_{4 \times 7}\right)$

\begin{tabular}{cccccccc}
\hline & $\boldsymbol{A}_{\mathbf{1}}$ & $\boldsymbol{A}_{\mathbf{2}}$ & $\boldsymbol{A}_{\mathbf{3}}$ & $\boldsymbol{A}_{\mathbf{4}}$ & $\boldsymbol{A}_{\mathbf{5}}$ & $\boldsymbol{A}_{\mathbf{6}}$ & $\boldsymbol{A}_{\mathbf{7}}$ \\
\hline$w$ & $s_{3}$ & $s_{4}$ & $s_{5}$ & $s_{4}$ & $s_{3}$ & $s_{3}$ & $s_{3}$ \\
\hline$a_{1}$ & $s_{3}$ & $s_{2}$ & $s_{1}$ & $s_{3}$ & $s_{5}$ & $s_{3}$ & $s_{3}$ \\
\hline$a_{2}$ & $s_{2}$ & $s_{2}$ & $s_{3}$ & $s_{3}$ & $s_{3}$ & $s_{2}$ & $s_{1}$ \\
\hline$a_{3}$ & $s_{2}$ & $s_{2}$ & $s_{2}$ & $s_{3}$ & $s_{4}$ & $s_{2}$ & $s_{3}$ \\
\hline$a_{4}$ & $s_{1}$ & $s_{4}$ & $s_{3}$ & $s_{1}$ & $s_{5}$ & $s_{2}$ & $s_{2}$ \\
\hline
\end{tabular}

Table 4. The information of weight and linguistic evaluation offered by the second expert $\left(W^{2}=\left(w_{j}^{2}\right)_{7}\right.$ and $\left.R^{2}=\left(r_{i j}^{2}\right)_{4 \times 7}\right)$

\begin{tabular}{cccccccc}
\hline & $\boldsymbol{A}_{\mathbf{1}}$ & $\boldsymbol{A}_{\mathbf{2}}$ & $\boldsymbol{A}_{3}$ & $\boldsymbol{A}_{\mathbf{4}}$ & $\boldsymbol{A}_{\mathbf{5}}$ & $\boldsymbol{A}_{\mathbf{6}}$ & $\boldsymbol{A}_{\mathbf{7}}$ \\
\hline$w$ & $s_{3}$ & $s_{5}$ & $s_{4}$ & $s_{4}$ & $s_{2}$ & $s_{3}$ & $s_{2}$ \\
\hline$a_{1}$ & $s_{4}$ & $s_{3}$ & $s_{2}$ & $s_{3}$ & $s_{1}$ & $s_{3}$ & $s_{2}$ \\
\hline$a_{2}$ & $s_{3}$ & $s_{2}$ & $s_{3}$ & $s_{3}$ & $s_{5}$ & $s_{2}$ & $s_{1}$ \\
\hline$a_{3}$ & $s_{1}$ & $s_{4}$ & $s_{2}$ & $s_{2}$ & $s_{3}$ & $s_{2}$ & $s_{4}$ \\
\hline$a_{4}$ & $s_{2}$ & $s_{1}$ & $s_{3}$ & $s_{2}$ & $s_{4}$ & $s_{3}$ & $s_{4}$ \\
\hline
\end{tabular}

Table 5. The information of weight and linguistic evaluation offered by the third expert $\left(W^{3}=\left(w_{j}^{3}\right)_{7}\right.$ and $\left.R^{3}=\left(r_{i j}^{3}\right)_{4 \times 7}\right)$

\begin{tabular}{cccccccc}
\hline & $A_{1}$ & $A_{2}$ & $A_{3}$ & $A_{4}$ & $A_{5}$ & $A_{6}$ & $A_{7}$ \\
\hline$w$ & $s_{3}$ & $s_{4}$ & $s_{4}$ & $s_{3}$ & $s_{3}$ & $s_{2}$ & $s_{2}$ \\
\hline$a_{1}$ & $s_{4}$ & $s_{2}$ & $s_{3}$ & $s_{2}$ & $s_{2}$ & $s_{1}$ & $s_{3}$ \\
\hline$a_{2}$ & $s_{2}$ & $s_{3}$ & $s_{2}$ & $s_{3}$ & $s_{2}$ & $s_{3}$ & $s_{2}$ \\
\hline$a_{3}$ & $s_{3}$ & $s_{2}$ & $s_{2}$ & $s_{4}$ & $s_{2}$ & $s_{1}$ & $s_{2}$ \\
\hline$a_{4}$ & $s_{2}$ & $s_{3}$ & $s_{2}$ & $s_{2}$ & $s_{3}$ & $s_{2}$ & $s_{4}$ \\
\hline
\end{tabular}

2. According to the Fuzzy semantic quantification criterion (selecting "most" from Table 2) and formula (6) and (7), we can get that: $\omega=(1 / 15,10 / 15,4 / 15)$.

3. According to the formula (9),

$$
z_{i}=\Psi_{4}\left[\left(x_{i}^{1}, \alpha_{i}^{1}\right),\left(x_{i}^{2}, \alpha_{i}^{2}\right), \cdots,\left(x_{i}^{p}, \alpha_{i}^{p}\right)\right]=\Delta\left(\sum_{j=1}^{p} \omega_{j} \beta_{j}\right),
$$

where $\beta_{j}=p \lambda_{\sigma(j)} \beta_{\sigma(j)}, \beta_{\sigma(j)}$ is the $j^{t h}$ largest elements of the set $\left(\beta_{1}, \cdots, \beta_{p}\right), \beta_{j}=\Delta^{-1}\left(x_{i}^{j}, \alpha_{i}^{j}\right)$, $j=1, \ldots, p$.

We can conclude that:

$$
z_{1}=\left(s_{3},-0.10\right), z_{2}=\left(s_{2}, 0.37\right), z_{3}=\left(s_{3},-0.27\right), z_{4}=\left(s_{2}, 0.31\right) .
$$


4. According to the comparison rules of two-tuple in section 3.2, we can rank the order of the agriculture informatization level of the four regions (shown as follows)

$$
a_{1} \succ a_{3} \succ a_{2} \succ a_{4} \text {. }
$$

In addition, we can conclude that the informatization level in four areas is between $s_{2}$ and $s_{3}$, and it shows little difference and has not yet reached the general level.

\section{Conclusion}

Agriculture informatization plays the key role in the process of achieving agriculture modernization; therefore, it's very important to construct the reasonable evaluation indicator system and evaluation method of agriculture informatization for understanding and accelerating the development of agriculture informatization. Less research on agriculture informatization evaluation system has been carried out in China now. In this paper, based on the correlative reference, we firstly analyze the present conditions of informatization evaluation indicator system and evaluation method, and we construct the evaluation indicator system of the agriculture informatization and the evaluation model of the agriculture informatization based on the two-tuple and relative operators. This model can not only be used to rank the order of informatization level of the different regions, but also realize the qualitative evaluation of the agriculture informatization of the different regions. Finally, an application example of the four regions in Shandong province shows that the evaluation system of the agriculture informatization constructed in this paper is effective, and the evaluation method proposed in this paper is simple and easy to use.

\section{Acknowledgment}

This paper is supported by the Humanities and Social Sciences Research Project of Ministry of Education of China (No. 09YJA630088), the Natural Science Foundation of Shandong Province (No. ZR2009HL022), the Social Science Planning Project Fund of Shandong Province (09BSHJ03), the Soft science project Fund of Shandong Province (2009RKA376), and the Doctor Foundation of Shandong Economic University. The authors also would like to express appreciation to the managing editor, Dr Jonas Šaparauskas and the anonymous reviewers for their very helpful comments on improving the paper.

\section{References}

Cho, Y. J.; Lee, S. H. 2007. Development of an Evaluation System of the Informatization Level for the Mould Companies in Korea, in Proceedings of the International Conference on Computational Science and its Applications, LNCS 4707, Part III, 8: 20-32.

Deciger, B.; Bi, X. Z. 2007. Discussing the role of rural web site in the process of agriculture informatization, Northern Economy 2: 116-118.

Herrera, F.; Martinez, L. 2000. A 2-tuple fuzzy linguistic represent model for computing with words, IEEE Transactions on Fuzzy Systems 8(6): 746-752. doi:10.1109/91.890332

Hou, Z. J. 2005. Study on the Evaluation Method of Informatization Level. Changchun University of Science and Technology. 
Information Week 500. 2003. Information Week. Available from Internet: <http://www.informationweek. com/iw500>, 2003.1.6.

Jung, Y. S.; Chin, S. Y.; Kim, K. R. 2004. Informatization Index for the Construction Industry, Journal of Computing in Civil Engineering 18(3): 267-277. doi:10.1061/(ASCE)0887-3801(2004)18:3(267)

Kaklauskas, A.; Zavadskas, E. K.; Naimaviciene, J.; Krutinis, M.; Plakys, V.; Venskus, D. 2010. Model for a Complex Analysis of Intelligent Built Environment, Automation in Construction 19(3): 326-340. doi:10.1016/j.autcon.2009.12.006

Liao, X. W.; Li, Y.; Dong, G. M. 2006. A Multi-attribute Group Decision-making Approach Dealing with Linguistic Assessment Information, Systems Engineering - Theory \& Practice (9): 90-98.

Li, T.; Luo, X. X. 2005. A Study on the dim synthetical assessment of the situation of informationization in colleges and universities, Journal of Hunan Economic Management College 5: 43-46.

Li, Y. S.; Wu, M.; Liu, J. H. 2006. Studies on the Selection of Index in the Evaluation of Construction of Agriculture Informatization in Countryside of China, Management of Agriculture Science and Technology 5: 66-68.

Machlup, F. 1962. The Production and Distribution of Knowledge in the United States. New Jersey: Princeton University Press.

Nagalingam, S. V.; Lin, G. C. I. 1998. A methodology to select optimal system components for computer integrated manufacturing by evaluating synergy, Computer Integrated Manufacturing Systems 11(3): 217-228. doi:10.1016/S0951-5240(98)00022-6

Porat, M. U.; Rubin, M. R. 1977. The Information Economy (9 volumes), Office of Telecommunications Special Publication 77-12 (US Department of Commerce, Washington D. C).

Ravi, K.; Murugan, A.; Magid, I. 1999. Selecting IT applications in manufacturing: a KBS approach, Omega 27(6): 605-616. doi:10.1016/S0305-0483(99)00029-8

Researching Group of China Informatization Level Research and Evaluation. 2006. Researching and Evaluation Report on Infromatizaiton Level of China, Statistical Research 2: 53-58.

Sheng, Q. F. 2005. A Study on Construction and Evaluation of Agriculture Informazation, Anhui Agriculture University 6: 22-30.

Song, L. 2001. Informatization level Calculating: theory and method. Beijing: Economic Science Press.

The group commissioner of Chinese People's Political Consultative Conference (CPPCC) China Public Interest Party proposed to increase efforts to promote rural informatization. 2007. Available from Internet: $<$ http://www.ltqy.com/content.asp?id=5815>.

Wei, F.; Liu, C. A.; Liu, S. Y. 2006. A method for group decision making with linguistic information based on uncertain information processing, Operations Research and Management Science 15(3): 42-46.

Yang, T. W. 2006. Synthetic Evaluation method of College Education Informatization level based on AHP and Gray Relation Analysis, China Higher Education Evaluation (3): 17-20.

Yan, T.; Li, Y. J. 2007. The Evaluation of Enterprise Informatization Performance Based on AHP/GHE/ DEA, in Proceedings of the International Conference on Management Science and Engineering 8: 149-156.

Yu, E. J.; Leem, C. S.; Park, S. K.; Kim, B. W. 2005. An integrated evaluation system for personal informatization levels and their maturity measurement: Korean motors company case, in Proceedings of the International Conference on Computational Science and Its Applications. LNCS 3482(1): 1306-1315.

Zavadskas, E. K.; Turskis, Z.; Tamošaitienè, J. 2010. Risk Assessment of Construction Projects, Journal of Civil Engineering and Management 16(1): 33-46. doi:10.3846/jcem.2010.03

Zhang, L. Y. 2006. Studies on the evaluation method of informatization model, Science \& Technology Progress and Policy (7): 37-40.

Zuo, M. Y.; Fu, H. J. 2007. Enterprise Informatization Maturity Model Based on Delphi Method, in Proceedings of IFIP International Federation for Information Processing, Boston: Springer, 10: 1117-1126. 


\section{ŽEMĖS ŪKIO INFORMATIZAVIMO LYGIO VERTINIMAS KOMPLEKSINIAIS SKAIČIAIS}

\section{P. Liu, X. Zhang}

Santrauka. Žemès ūkio informatizavimo lygis yra labai svarbus šalies modernizavimui. Labai svarbu suformuoti pagrịstą žemès ūkio informatizavimą apibūdinančią rodiklių sistemą ir pasiūlyti jo vertinimo metodą. Iš pradžių straipsnyje analizuojami panašūs vertinimai, atlikti šalyje ir užsienyje. Remiantis šia analize buvo suformuota Kinijos žemès ūkio informatizavimo rodiklių sistema, sukurtas kompleksiniais skaičiais pagrịstas žemès ūkio informatizavimo vertinimo modelis. Šis modelis gali ne tik surikiuoti šalies rajonus pagal jų informatizavimo lygị, bet ir atlikti jų kokybinị vertinimą. Skaitinis pavyzdys atskleidžia, jog žemės ūkio informatizavimo rodiklių sistema ir vertinimo metodas yra geri ir veiksmingi.

Reikšminiai žodžiai: žemès ūkio informatizavimas, kompleksinis skaičius, lingvistinis vertinimas.

Peide LIU (China, 1966) obtained his doctor degree in information management in the Beijing Jiaotong University. His main research fields are technology and information management, decision support and electronic-commerce. He was engaged in the technology development and the technical management in the Inspur company a few years ago. Now he is a full-time professor in Shandong Economic University and assistant director of the Enterprise's Electronic-commerce Engineering Research Center of Shandong.

Xin ZHANG (China, 1967) obtained his doctor degree in information management in the Beijing Jiaotong University. At present, he is the dean of school of Information Management at Shandong Economic University and also is a professor of management science and engineering. His main research focuses on information management and technology, knowledge management, and knowledge-based systems. 